\title{
ASSESSMENT AND REHABILITATION OF A HERITAGE MASONRY BUILDING IN PIRAEUS, GREECE
}

\author{
CHRYSANTHOS MARAVEAS ${ }^{1,2} \&$ FOTIOS ANDRIS ${ }^{2}$ \\ ${ }^{1}$ Department of Civil Engineering, University of Patras, Greece \\ ${ }^{2}$ Stuctures \& Civils Section, Maraveas \& Associates P.C., Greece
}

\begin{abstract}
This paper presents the assessment, rehabilitation and strengthening of a heritage masonry structure in Piraeus, Greece. The two-storey structure was constructed around 1900 and is used as a student restaurant at the University of Piraeus. The geometry is complex for a masonry structure and, furthermore, the masonry walls have been prestressed via wrought-iron tendons. The floors are constructed with the jack-arch method, supported by steel girders. This study was particularly challenging because of uncertainties regarding the properties of the structural materials and alterations to the live loads related to the change in the use of the building. Because the building has been declared a protected monument by the Greek State, the primary concern of the suggested retrofit was the preservation of its architectural and historical value. Thus, additional issues arose in the effort to minimize interventions. Extensive numerical simulations are presented and an extended discussion is included regarding the appropriate rehabilitation and strengthening techniques in order to satisfy both the basic principles for heritage rehabilitation and the required safety level.

Keywords: historical buildings, masonry, retrofit, strengthening, restoration.
\end{abstract}

\section{INTRODUCTION}

The new city of Piraeus was planned as the port of Athens in 1834. The economic growth based on trade, industry and shipping led Piraeus to become the most important port in Greece and the Mediterranean during the 19th century [1]. This in turn resulted in the construction of many beautiful, neoclassical buildings like the one discussed in this paper. The building examined in this study was built in the first half of the 20th century, is one of the 359 listed buildings in the city of Piraeus and is a paragon of Greek heritage and architecture.

This paper proposes structural strengthening for the historical masonry structure under consideration. First, the load-carrying system of the building is assessed and then used to create a finite-element model, for which the Robot Structural Analysis software [2] is used. Moreover, the material properties must be simulated realistically to minimize the uncertainties associated with the mechanical properties. Precise modelling of the building's geometry and the analyses used provide an accurate insight into the structural response. Finally, retrofitting measures based on non-destructive methods are proposed.

\section{DESCRIPTION OF GEOMETRY}

The building studied in this paper has two levels and is currently used as a restaurant for the students of the University of Piraeus. It has a rectangular layout with approximate dimensions of $23.9 \mathrm{~m} \times 12.00 \mathrm{~m}$, covers a total area of approximately $576 \mathrm{~m}^{2}$ and is partly covered by a timber roof. Therefore, the walls along one main direction are nearly twice the length of those in the other main direction.

The heights of the two levels and the roof are $4.30 \mathrm{~m}, 3.70 \mathrm{~m}$ and $1.0 \mathrm{~m}$, respectively. Because of the architectural requirement of day lighting, each wall has several large openings with dimensions of $1.15 \mathrm{~m} \times 2.20 \mathrm{~m}$, occupying approximately $20 \%$ of the surface of each wall. Inevitably, this reduces the strength of the walls. Their thickness varies from $0.25-0.70$ $\mathrm{m}$ for the internal walls to $0.80 \mathrm{~m}$ for the external walls. Moreover, there is a $0.50 \mathrm{~m}$-thick 
unreinforced masonry parapet in the perimeter of the top level. Photographs of the exterior of the building (façade) are shown in Fig. 1, while plan views of the ground and first floors are presented in Fig. 2.

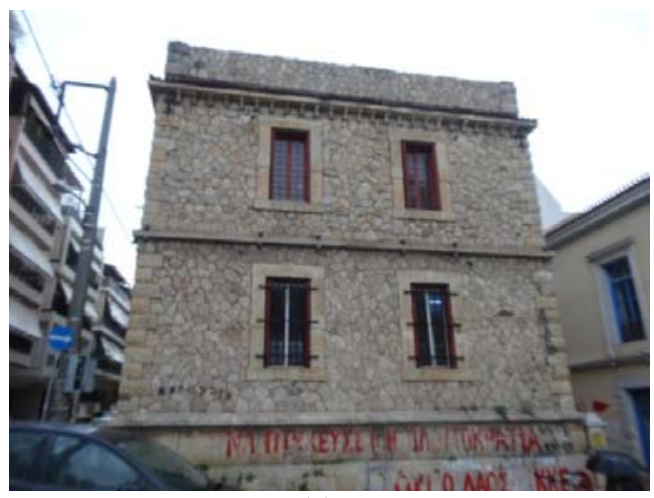

(a)

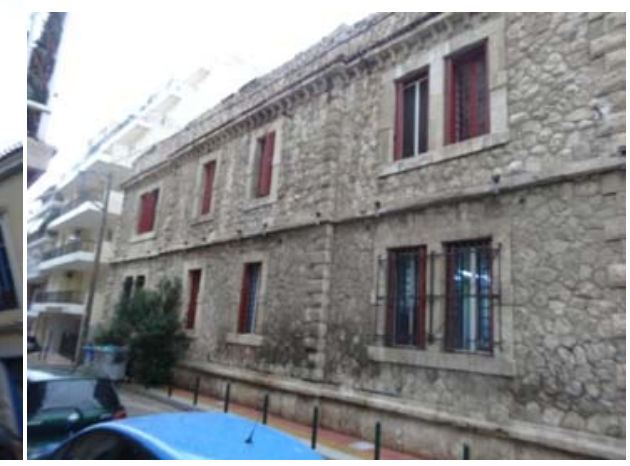

(b)

Figure 1: Exterior façades of building. (a) Northern; (b) Western.

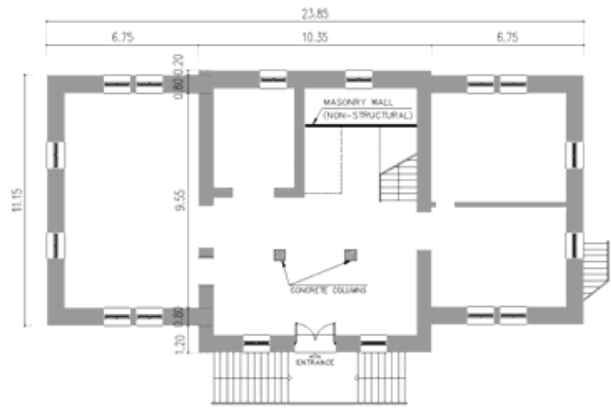

(a)

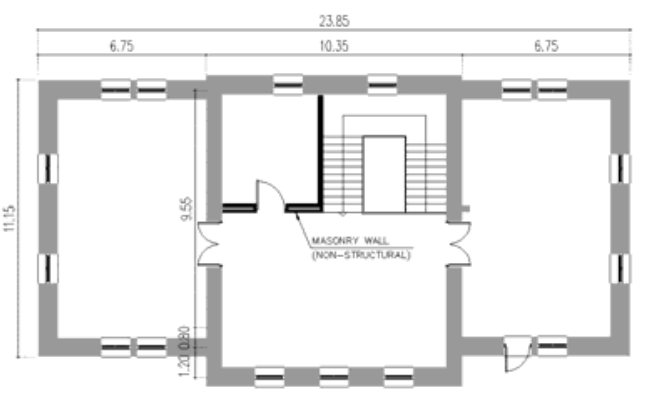

(b)

Figure 2: Plan views: (a) ground floor; (b) first floor.

\section{MATERIAL PROPERTIES}

As is the case with most historical masonry buildings [3], [4], the available data on the material properties were insufficient. Thus, the mechanical characteristics of the various elements constituting the masonry had to be specified through experiments by the contractor. State-of-the-art methods for specifying material properties can be found in the literature [5][7]. However, for the examined building, common laboratory tests were conducted for calculating the mechanical characteristics of the various elements constituting the masonry. More specifically, five masonry units and three mortar samples were extracted from different locations of the building and subjected to mono-axial compression tests and granular and chemical analyses, respectively. The results of these tests showed the normalized mean compressive strength $f_{\mathrm{b}}$ of the units in the direction of the applied action to be $43 \mathrm{MPa}$ and the compressive strength $f_{\mathrm{m}}$ of the mortar to be $1.19 \mathrm{MPa}$. With these two properties having been obtained, the characteristic compressive strength $f_{\mathrm{k}}$ and shear strength $f_{\mathrm{vk} 0}$ of the masonry 
are calculated easily using equations provided in EN 1996-1-1 [8]. Additionally, two perforation tests were performed to define the slab thickness, while steel section profiles were obtained from two different locations of the jack-arch slab to measure their dimensions. Finally, the foundation of the building was examined so that possible issues could be investigated.

\section{STRUCTURAL CHARACTERISTICS}

As shown in Fig. 1, large limestones have been used at the corners where large stress concentrations are expected. Every corner stone is flanked by two others perpendicular to it. This arrangement of corner stones plays a fundamental role in ensuring an effective connection between perpendicular walls. Thus, this construction technique in historical masonry buildings contributes significantly to their monolithic response.

Regarding the slab of the ground floor, it comprises a jack-arch system (Fig. 3(a)), while for the roof of the first floor the same composite system is used only in the part not covered by the timber roof, as shown in Fig. 3(b).
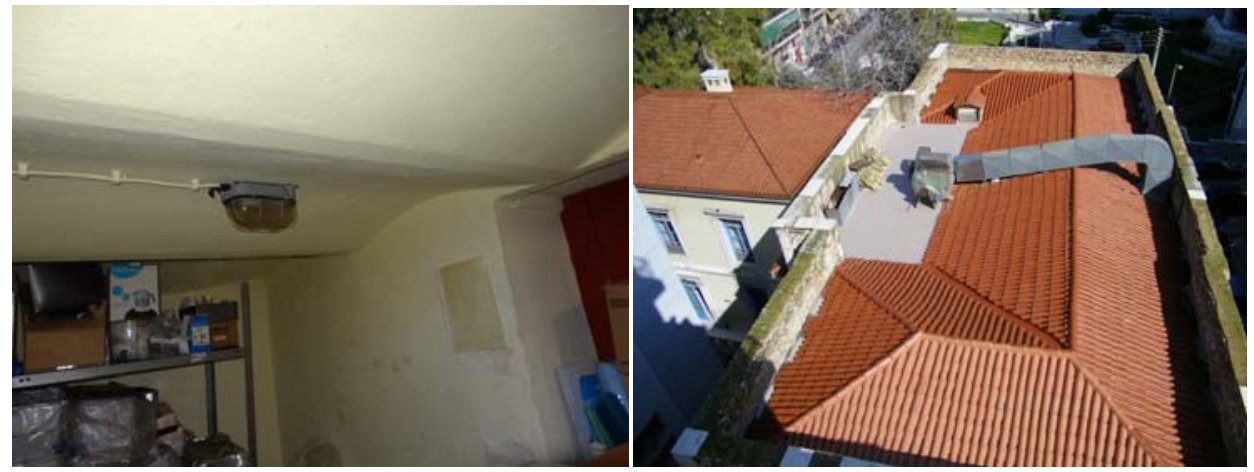

Figure 3: Structural characteristics. (a) Configuration of jack-arch slab; (b) Location of roof where jack-arch slab is present.

Extensive research has been conducted into how composite steel-concrete slabs benefit a building's response. El-Mahdy [9] notes that beams encased in concrete lead to reduced deformations, while Maheri [10] concludes that the extensive use of jack-arch slabs as floors in residential and industrial buildings results from their relatively low cost and easy application. The same conclusion is drawn in Oliveira and Debs [11], where it is also noted that in the case of composite slabs, steel profiles act as formwork during construction and as reinforcement in the service state.

Diaphragm action for the roof of the second floor is provided partially by the use of wrought-iron tie rods running along all longitudinal and transverse walls (Fig. 4(a)) and anchored in steel ties like those encircled in green in Fig. 4(b). The use of such steel ties in historical masonry structures can increase the load capacity of the participating walls [12]. It is also highlighted in Corradi et al. [13] that strengthening with steel cords significantly increases the compression and shear strength of the walls. However, as is stated in MoraGómez [12] and Calderini et al. [14], increasing the pre-tension in the iron tie rods does not increase the collapse load by much. 


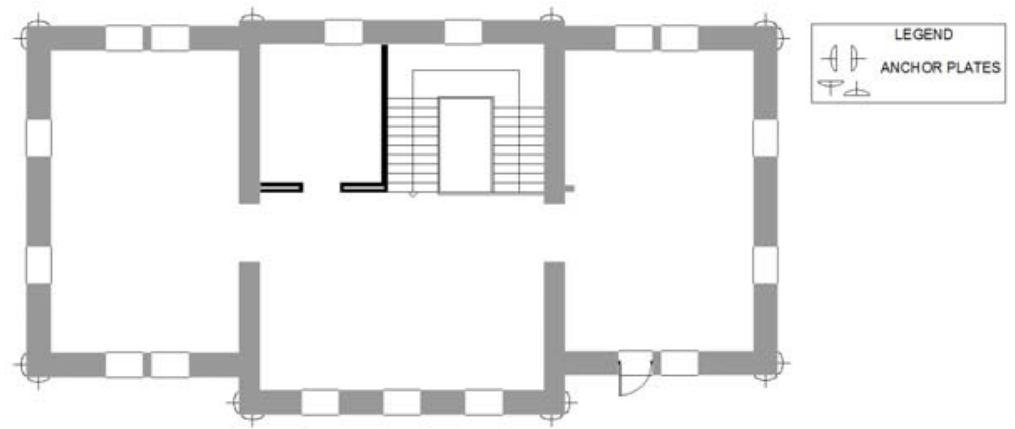

(a)

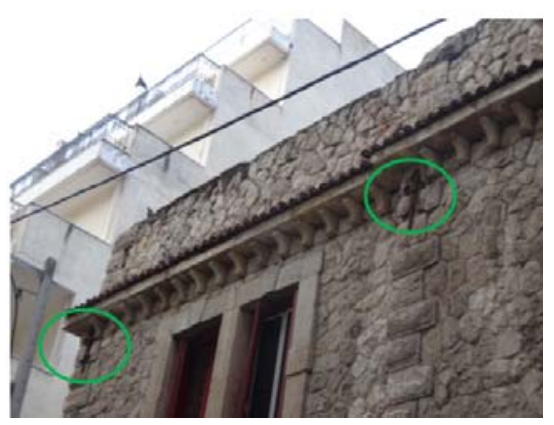

(b)

Figure 4: System of wrought-iron tie rods. (a) Locations of anchor plates on exterior walls of first floor; (b) Configuration of anchor plates (encircled in green).

\section{BUILDING PATHOLOGY AND RETROFITTING MEASURES}

The building is generally in good condition. This is related to the fact that the masonry walls are well connected to each other through effective floor diaphragms that secure the box behaviour of the building under horizontal loads.

It is widely accepted in the literature [15]-[18] that in the absence of floor diaphragms extensive damage is expected. The reason for this is that in the absence of rigid diaphragms, the walls act as cantilevers instead of simply supported panels. This increases the out-ofplane bending of the masonry, thereby causing excessive damage because masonry has almost no ability to resist tension. Unfortunately, in historical masonry buildings, it is more than likely that there are no floor diaphragms at all. Asteris and Giannopoulos [19] also noted that traditional masonry structures were built with their geometry and aesthetic quality being the primary concerns, not their structural integrity.

To relieve walls of high out-of-plane bending values, it is desirable that they be as short as possible lengthwise. Fortuitously, as can be seen from the structural layout (Fig. 2), the walls on the long dimension of the examined building intersect with the two interior walls at two points. Moreover, the interior walls are sufficiently thick and long and without many openings. Thus, they can provide lateral support to the walls on the long dimension. Put simply, the transverse walls divide the unsupported length of the walls on the long dimension into three parts, thereby reducing their out-of-plane displacements. This, combined with the fact that the composite slab at the top of the ground floor as well as the steel ties at the top of 
the first floor provide diaphragm action, reduces the likelihood of serious damage associated with an excessive out-of-plane response of the walls. However, the following deficiencies were recorded during the site visit:

- indications of corrosion are visible on the structural members of the timber roof;

- cracks on the stairs slab of the internal staircase;

- an unreinforced masonry parapet in the perimeter of the top level is prone to out-ofplane rocking behaviour;

- detachment of the coating at several parts of the building due to moisture and oxidation of the steel profiles supporting the jacked arches.

The first three defects are shown in Fig. 5 and are elaborated in the following sections.

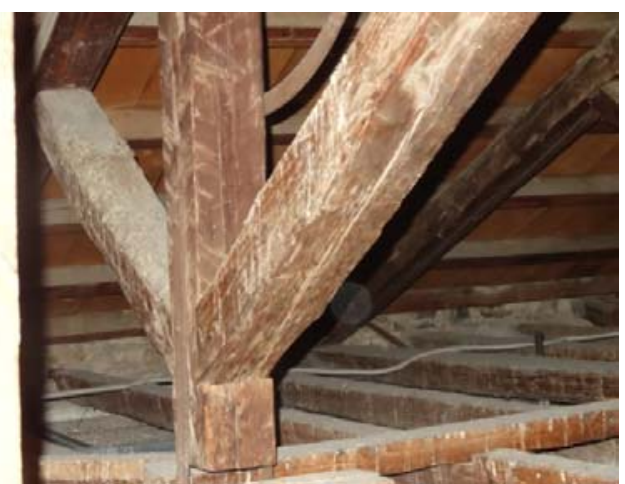

(a)

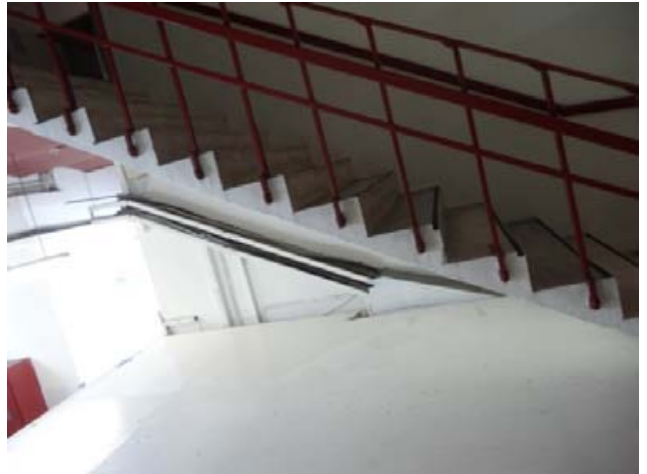

(b)

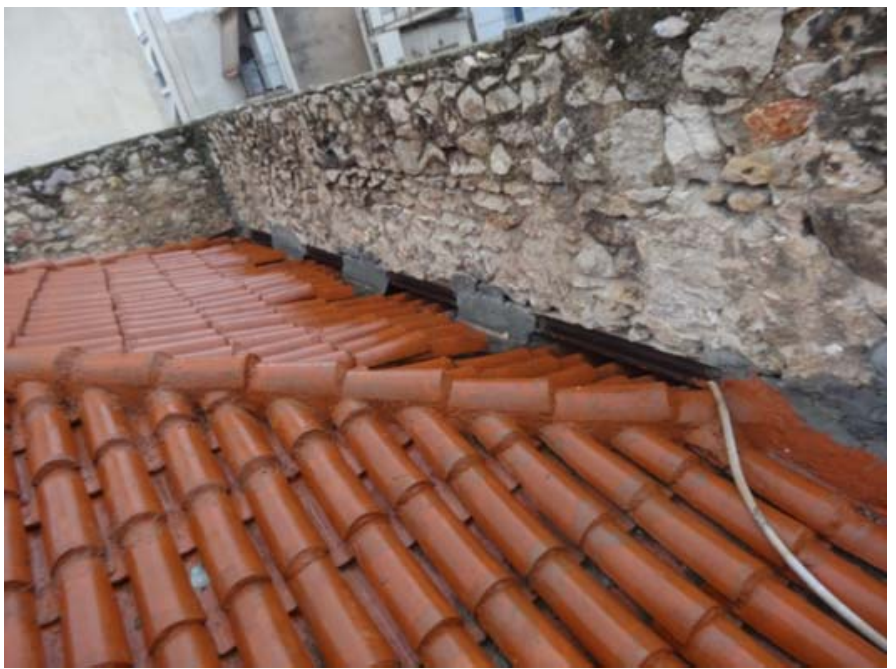

(c)

Figure 5: Building's pathology. (a) Typical truss having experienced corrosion by rainwater; (b) Statically insufficient thickness of stairs slab; (c) Masonry parapet in perimeter of top level. Restoration proposal requires its removal. 


\subsection{Timber roof}

The timber roof is significantly damaged. Although the structural members of the trusses do not appear to have experienced failure, some of the trusses exhibit excessive corrosion (Fig. 5(a)) due to rainwater that was not blocked effectively by the roof tiles. Furthermore, the roof purlins have suffered large deflections.

\subsection{Internal staircase}

Changing the building from a house to a restaurant resulted inevitably in the structure having to withstand new, significantly increased live loads. The appearance of cracking on the internal staircase (Fig. 5(b)) can be attributed to this fact and to the thinness of the stair slab (around $5 \mathrm{~cm}$ ) for the required cantilever action.

\subsection{Masonry parapet}

Additionally, the unreinforced masonry parapet in the perimeter of the top level (Fig. 5(c)) poses a threat to passers-by in case of a seismic event because it is insufficiently supported on steel section profiles.

\section{DESIGN PRINCIPLES}

\subsection{Applied codes}

In addition to the weight of the structure itself, distributed dead loads of $1.2 \mathrm{kN} / \mathrm{m}^{2}$ and $0.5 \mathrm{kN} / \mathrm{m}^{2}$ were considered for the floors and the timber roof, respectively, while the loads imposed on the floor and the roof were $3.0 \mathrm{kN} / \mathrm{m}^{2}$ and $1.0 \mathrm{kN} / \mathrm{m}^{2}$, respectively, as proposed in EN 1991-1-1 [20]. Snow and wind actions were also taken into account through the provisions of EN 1991-1-3 [21] and EN 1991-1-4 [22], respectively.

Based on EN 1998-1-1 [23], an inelastic response spectrum was adopted for soil type D ( soil factor $S=1.35$; characteristic response spectrum periods $T_{\mathrm{B}}=0.2 \mathrm{~s}, T_{\mathrm{C}}=0.8 \mathrm{~s}$ and $T_{\mathrm{D}}=$ $2.5 \mathrm{~s}$; design ground acceleration $a_{\mathrm{g}}=0.16 \mathrm{~g}$; importance factor $\gamma_{\mathrm{I}}=1.20$; behaviour factor $q$ $=1.50$ ). Finally, the load combinations used were in accordance with EN 1990 [24].

\subsection{Structural evaluation of building}

The design resistances of unreinforced masonry, according to EN 1996-1-1 [25], were used to check the results of the analyses and are summarized below:

$$
\begin{gathered}
N_{\mathrm{Rd}}=\frac{\Phi t f_{\mathrm{k}}}{\gamma_{\mathrm{M}}}, \\
V_{\mathrm{Rd} 1}=\frac{f_{\mathrm{vk} 0}+0.4 \sigma_{0}}{\gamma_{\mathrm{M}}} b t \\
V_{\mathrm{Rd} 2}=\frac{1.5 f_{\mathrm{vk} 0} b t}{\gamma_{\mathrm{M}}} \sqrt{1+\frac{\sigma_{0}}{1.5 f_{\mathrm{vk} 0}}} \\
M_{\mathrm{Rd}}=\frac{\sigma_{0} b^{2} t}{2}\left(1-\frac{\sigma_{0}}{0.85 f_{\mathrm{d}}}\right) .
\end{gathered}
$$


Note that the capacity of the two walls supporting the internal staircase to withstand the concentrated loads applied on them was checked by hand according to the provisions of EN 1996-1-1 [25].

\section{NUMERICAL ANALYSES}

\subsection{Finite-element models}

When studying the response of masonry buildings, using shell elements is the most effective way to model the in- and out-of-plane behaviour of walls because of the ability of shell elements to capture flexural deformations and membrane forces accurately. In this case study, four-node shell elements were used with thicknesses of $0.25-0.80 \mathrm{~m}$ according to the actual thicknesses of the exterior and interior walls of the building. A convergence analysis was necessary to define the finite element size. Pinned connections were assumed for the boundary conditions of the mathematical model because no failures indicating foundation or soil failure were recorded during the site investigation. Note that for reasons of simplicity, the effect of the wrought-iron tie rods was neglected. Additionally, the composite slab was not considered explicitly in the finite-element model. More specifically, an equivalent thickness of reinforced concrete slab was used, taking into account the material properties of the jack-arch system (i.e. the properties of the concrete and steel sections). Given that the jack-arch system is considered sufficient to provide diaphragm action, the rigid-diaphragm option in the software was used only where this system is present (Fig. 6).

The timber roof was not included at all in the finite-element model because practically its connection to the masonry walls is almost impossible to achieve. This is due to the fact that the huge lateral stiffness of the masonry walls makes the in-plane stiffness of the floor insignificant. However, typical lattice trusses of the roof were modelled and then solved under the characteristic imposed snow and wind loads acting on them. The reactions of each load case where then transferred to the respective node of the three-dimensional model (Fig. $6)$.

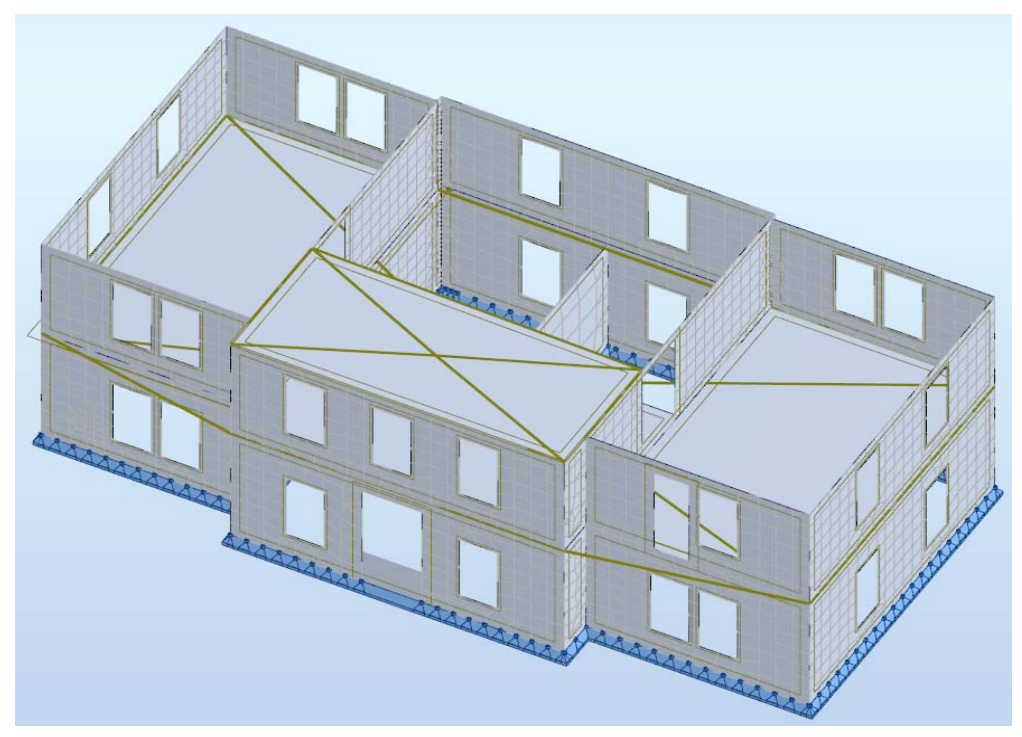

Figure 6: Finite-element model of structure. 


\section{STRENGTHENING PROPOSAL}

As in most cases of retrofitting historical buildings [26], the strengthening methods should not alter the traditional architectural characteristics of the building. In particular, because an effective repair of the timber roof would be rather unfeasible or at least cost-ineffective, the design team decided on removing the roof completely and constructing a new one. The new timber roof will have a similar configuration to that of the existing one and will be adequately connected to the masonry walls so that rigid diaphragm action can be achieved.

Moreover, to relieve the internal staircase from its cracking, the external bonding of the two walls that are supporting it is proposed through textile-reinforced mortar (TRM). The advantages of this strengthening method over similar ones are studied extensively in Papanicolaou et al. [27] and Tetta et al. [28], where TRM is compared with fibre-reinforced polymer (FRP) as the strengthening material.

Stainless-steel sections are also suggested as a means of interconnecting the walls of the parapet. This strengthening method is expected to contribute significantly to making potential out-of-plane rocking behaviour of the parapet unlikely.

Finally, the steel sections participating in the jack-arch system that have been diagnosed with oxidation will be repaired through sandblasting.

Note that of all the aforementioned strengthening techniques, only the one involving adding a rigid diaphragm at the top of the first floor was considered in the modified mathematical model (Fig. 7). The reason for this is that the other restoration measures are unlikely to have a significant effect on the global behaviour of the building. Note also that because the configuration of the new timber roof will follow closely that of the existing one, all the loads transferred from the timber trusses to the masonry walls will be equal to the initial ones.

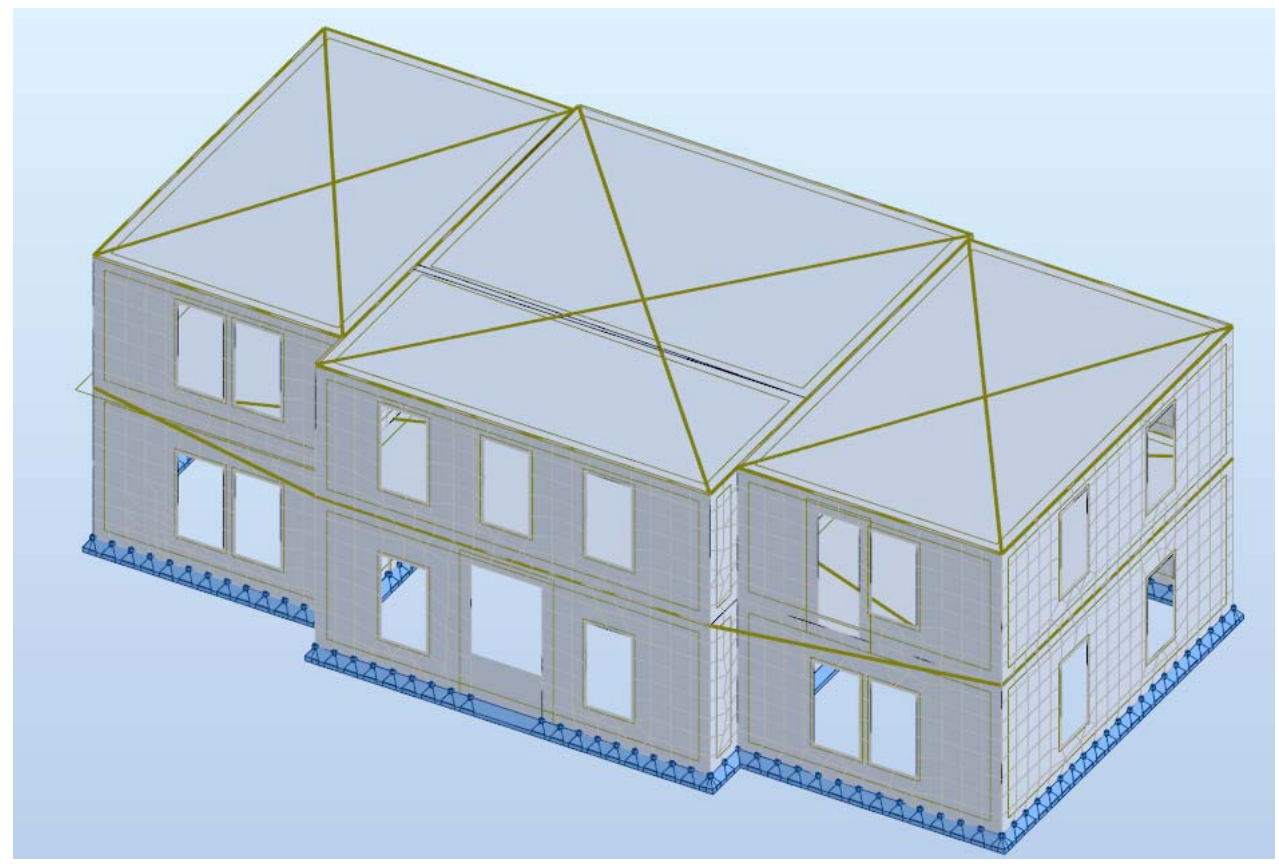

Figure 7: Finite-element model in Robot Structural Analysis software after strengthening proposal. 


\section{COMPARISON OF RESULTS}

In Fig. 8, the results for the bending moments and the displacements in both main directions are compared for the initial structure and the strengthened one. In the absence of a diaphragm at the top level, the walls of the first floor behave as cantilevers in practice. Consequently, while the bending moments and displacements have low values within the walls of the ground floor, they increase freely from the base to the top of the first floor. In the strengthened model, shear forces, displacements and bending moments were limited to low values.

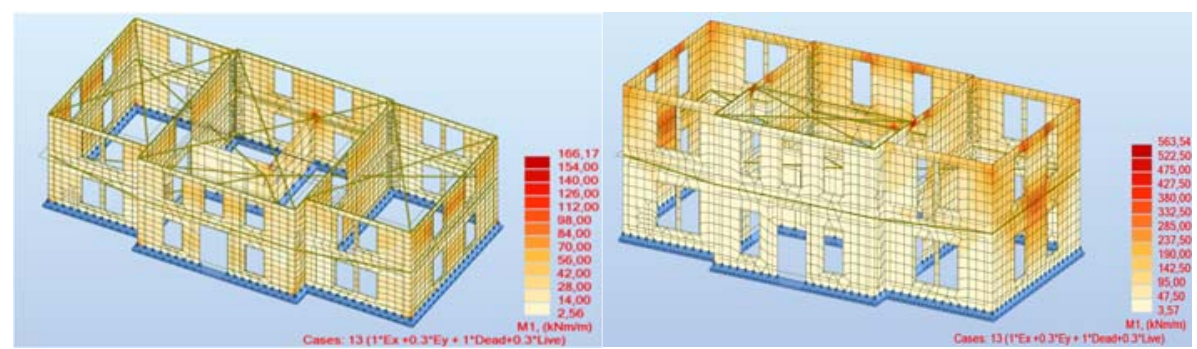

(a)

(b)

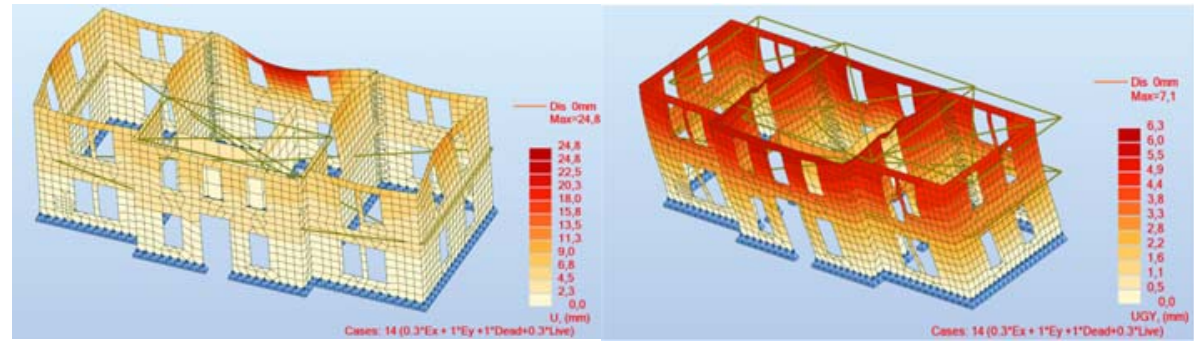

(c)

(d)

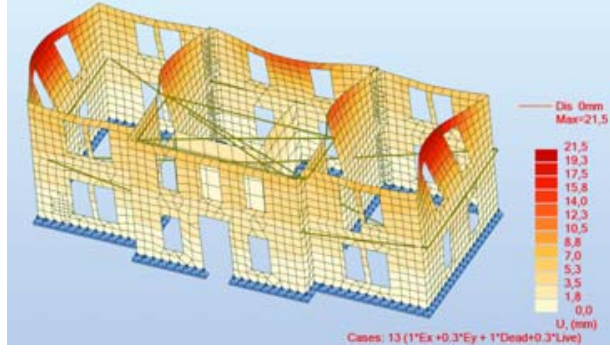

(e)

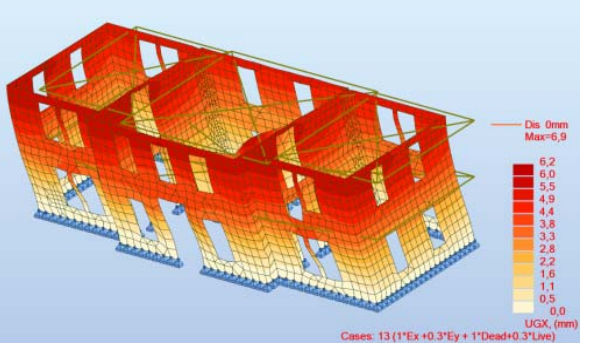

(f)

Figure 8: Indicative analysis results after strengthening proposal. (a), (b) Principal bending moment M1 (kN·m/m); (c), (d) Global displacements in X direction (mm); (e), (f) Global displacements in Y direction (mm).

Table 1 allows comparison of various results obtained from analysing the existing structure and the retrofitted one. The results refer to the maximum principal bending moment, shear force and global displacement of the structure. All values for the retrofitted section satisfied the design checks [25]. Note also that the modal frequencies of the retrofitted building are higher than those of the existing building owing to an increase in stiffness associated with the presence of floor diaphragms. 
Table 1: Comparative results for initial building and strengthened one.

\begin{tabular}{|c|c|c|c|c|}
\cline { 2 - 5 } \multicolumn{1}{c|}{} & $\begin{array}{c}\text { Max. } \\
\text { moment } \\
(\mathrm{kN} \cdot \mathrm{m} / \mathrm{m})\end{array}$ & $\begin{array}{c}\text { Max. } \\
\text { shear } \\
(\mathrm{kN} / \mathrm{m})\end{array}$ & $\begin{array}{c}\text { Max. } \\
\text { displacement } \\
\text { Ux }(\mathrm{mm})\end{array}$ & $\begin{array}{c}\text { Max. } \\
\text { displacement } \\
\text { Uy }(\mathrm{mm})\end{array}$ \\
\hline $\begin{array}{c}\text { Before } \\
\text { retrofit }\end{array}$ & 563.54 & 1382.661 & 21.5 & 24.8 \\
\hline $\begin{array}{c}\text { After } \\
\text { retrofit }\end{array}$ & 166.17 & 566.67 & 6.9 & 7.1 \\
\hline
\end{tabular}

\section{CONCLUSIONS}

1. The initial building is characterized by compact box behaviour that is attributed to the adequate connection of intersecting walls, the lack of long unsupported walls and the existence of rigid diaphragms and wrought-iron tie rods at the top of the ground floor and first floor, respectively. For this reason, the building has experienced no earthquakerelated damage.

2. Some defects were recorded during the site visit, such as corroded trusses of the timber floor, cracks on the stair slab of the internal staircase, an improperly supported parapet and some oxidized steel sections participating in the jack-arch system. However, these defects are irrelevant to the global response of the building.

3. Even with only the addition of a rigid diaphragm at the top of the first floor considered in the strengthened model and all the other retrofitting measures ignored, the structural behaviour of the building is improved significantly.

4. Not only did the maximum displacements decrease as a result of the diaphragm, the difference in terms of the maximum displacement between the orthogonal directions also decreased. This is related to the improved box behaviour of the building resulting from adding a second rigid diaphragm.

5. Introducing rigid diaphragms led to the structural performance complying with the given codes, even with more-sophisticated methods of seismic assessment. The key aspects of this method are that it is relatively cost-effective, reversible and alters the appearance of the building only minimally.

6. The presence of rigid diaphragms decreased the structure's fundamental period. Therefore, for structures founded on soft soil and characterized by a long period, this retrofitting method could also be beneficial by preventing dynamic amplifications generated by the resonance between the underlying soil layers and the superstructure. Conversely, this strengthening method should be selected carefully for structures founded on firm soil because a further decrease in the structure's fundamental period could lead to the tuning of the soil-structure system, with detrimental effects on its seismic performance.

\section{REFERENCES}

[1] Malikouti, S., Piraeus 1834-1912, Cultural Institute of Piraeus, 2004. (In Greek.)

[2] Autodesk Robot Structural Analysis Professional v.29.0, 2016. Online. https://www.autodesk.com/products/robot-structural-analysis/overview.

[3] Maraveas, C., Tasiouli, K. \& Fasoulakis, Z., Assessment of the new Faliron steamelectric station in Greece. 14th International Conference on Studies, Repairs and Maintenance of Heritage Architecture, A Coruña, Spain, pp. 247-259, 2015. 
[4] Maraveas, C. \& Tasiouli, K., Assessment and restoration of the first Greek power plant - registered monument of industrial heritage. Case Studies in Structural Engineering, 2, pp. 1-10, 2015.

[5] Boscato, G., Di Tomasso, A., Guerra, F., Lazzarini, L., Mazzucato, A. \& Pizzolato, M. Approach and methodology in understanding the structural behaviour of historic arch bridges through dynamic monitoring: the case of Rialto Bridge in Venice. Proceedings of 34th IABSE Symposium on large structures and infrastructures for environmentally constrained and urbanised areas, ed. A. Steffen, Venice, Italy, September 22-24, Zurich: International Association for Bridge and Structural Engineering, 2010.

[6] Boscato, G., Dal Cin, A., Riva, G., Russo, S. \& Sciarretta, F., Knowledge of the construction technique of the multiple leaf masonry façades of Palazzo Ducale in Venice with ND and MD tests. Advanced Materials Research, 919-921, pp. 318-324, 2014.

[7] Sciarretta, F., Antonelli, F., Peron, F. \& Caniglia, S., Final outcomes on the multidisciplinary long-term monitoring and preservation state investigation on the medieval external Façades of Palazzo Ducale in Venice, Italy. Journal of Civil Structural Health Monitoring, 8(1), pp. 111-133, 2018.

[8] EN 1996-1-1, Eurocode 6- Design of masonry structures-Part 1-1: general rules for reinforced and unreinforced masonry structures. CEN, Brussels, 2005.

[9] El-Mahdy, O., Structural behavior of concrete encased steel beams. Ain Shams Engineering Journal, 40(4), pp. 87-99, 2005.

[10] Maheri, M., Seismic evaluation and design of jack arch slabs. 13th World Conference on Earthquake Engineering, Vancouver, B.C., Canada, paper no. 3028, 2004.

[11] Oliveira, L. \& Debs, A., Evaluation of the in service behavior of steel-concrete composite slabs. Proceedings of the Fib Symposium 2019: Concrete Innovations in Materials, Design and Structures, Krakow, Poland, May 27-29, 2019.

[12] Mora-Gómez, J., Historical iron tie-rods in vaulted structures: parametrical study through a scaled model. WIT Transactions on the Built Environment, vol. 153, WIT Press: Seville, pp. 669-680, 2015.

[13] Corradi, M., Borri, A., Giannantoni, A. \& Speranzini, E., Reinforcement of historic masonry with high strength steel cords. Masonry International, 23, pp. 79-90, 2010.

[14] Calderini, C., Lagomarsino, S., Rossi, M., Decanio, G., Mongelli, M. \& Roselli, I. Seismic behaviour of masonry arches with tie-rods: dynamic tests on a scale model. 15th WCEE World Conference on Earthquake Engineering, Lisbon, Portugal, September 24-28, 2012.

[15] Tomaževič, M., Earthquake-Resistant Design of Masonry Buildings, Imperial College Press, 1999.

[16] Langroudi, J., Ranjbar, M., Hashemi, S. \& Moghadam, A., Evaluation of roof diaphragm effect on seismic behavior of masonry buildings. Proceedings of the 8th International Conference on Structural Dynamics, Leuven, Belgium, 4-6 July, 2011.

[17] Gabellieri, R., Diotallevi, P.P. \& Landi, L., Effect of diaphragm flexibility on the dynamic behaviour of unreinforced masonry walls in out-of-plane bending. 15th World Conference on Earthquake Engineering (15WCEE), Lisbon, Portugal, pp. 24-28, 2012.

[18] Simsir, C., Aschheim, M. \& Abrams, D., Influence of diaphragm flexibility on the outof-plane response of unreinforced masonry walls. Proceedings of the 9th Canadian Masonry Symposium, Fredericton, Canada, 2001. 
[19] Asteris, P.G. \& Giannopoulos, I.P., Vulnerability and restoration assessment of masonry structural systems. Electronic Journal of Structural Engineering, 12(1), pp. 82-93, 2012.

[20] EN 1991-1-1, Eurocode 1: Actions on structures-Part 1-1: General actions - Densities, self-weight, imposed loads for buildings. CEN, Brussels, 2002.

[21] EN 1991-1-3, Eurocode 1: Actions on structures-Part 1-3: General actions - Snow loads. CEN, Brussels, 2003.

[22] EN 1991-1-4, Eurocode 1: Actions on structures-Part 1-4: General actions - Wind actions. CEN, Brussels, 2005.

[23] EN 1998-1-1, Eurocode 8-Design of structures for earthquake resistance-Part 1: general rules, seismic actions and rules for buildings. CEN, Brussels, 2003.

[24] EN 1990, Eurocode - Basis of structural design. CEN, Brussels, 2002.

[25] EN 1996-1-1, Eurocode 6-Design of masonry structures-Part 1-1: general rules for reinforced and unreinforced masonry structures. CEN, Brussels, 2005.

[26] Maraveas, C., Miamis, K., Tasiouli, K. \& Fasoulakis, Z., Structural analysis and retrofitting of "Tzotza" building in Kastoria, Greece. 9th International Conference on Structural Analysis of Historical Construction, Mexico City, Mexico, paper 13_003, 2014.

[27] Papanicolaou, C.G., Triantafillou, T.C., Karlos, K. \& Papathanasiou, M., Textilereinforced mortar (TRM) versus FRP as strengthening material of URM walls: inplane cyclic loading. Materials and Structures, 40, pp. 1081-1097, 2007.

[28] Tetta, Z.C., Koutas, L.N. \& Bournas, D.A., Textile-reinforced mortar (TRM) versus fiber-reinforced polymers (FRP) in shear strengthening of concrete beams. Composites Part B: Engineering, 77, pp. 338-348, 2015. 